\title{
2IT-BAD Monoclonal Antibody 170
}

National Cancer Institute

\section{Source}

National Cancer Institute. 2IT-BAD Monoclonal Antibody 170. NCI Thesaurus. Code C2538.

An immunoconjug ate of a metal chelator, 2IT-BAD (2-iminothiolane-2-[p-

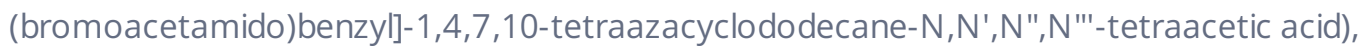

and a panadenocarcinoma murine monoclonal antibody (MoAb) m170. MoAb m170

recognizes MUC-1 antigen present on the surface of many adenocarcinomas. 2IT-BAD

MoAb m170 can readily chelate any radioisotope and be used in diagnostic procedures or in the treatment of MUC-1 expressing adenocarcinomas. 